Vol. 54, z. 2 - 2001

s. $47-57$

\title{
Evapotranspiration of osteospermum 'Denebola' and New Guinea impatiens 'Timor' grown on ebb-and-flow benches as affected by climate conditions and soil water potential
}

\section{JADWIGA TREDER, JOANNA NOWAK}

\author{
Research Institute of Pomology and Floriculture,96-100 Skierniewice, Pomologiczna 18, \\ Poland \\ jtreder@insad.isk.skierniewice.pl
}

(Received: 1.06. 2001)

\section{$\mathrm{Sum} \mathrm{m}$ ar $\mathrm{y}$}

Daily evapotranspiration (EVPT) of two bedding plants osteospermum 'Denebola' and impatiens 'Timor' grown on ebb-and-flow benches was measured by weighing method, together with assessment of indoor climate parameters (solar radiation, temperature, humidity) and leaf area index (LAI) at different growth phases. The evaporation inside the greenhouse as affected by climatic factors i.e.: solar radiation, temperature, humidity and air velocity was also measured using Piche's evaporometer. Plants were irrigated according to soil water potential (irrigation at $-0.5 ;-3 ;-10$ and $-20 \mathrm{kPa}$ ). Irrigation at high water potential decreased plant growth and leaf area of both plants. LAI of osteospermum decreased as water deficit increased. In the case of impatiens, the highest LAI at full flowering obtained plants irrigated at $-3 \mathrm{kPa}$.

The actual, daily EVPT of plants irrigated at $-0.5 \mathrm{kPa}$ increased with plant growth in the case of osteospermum while that of impatiens remained at similar level. At flowering water stress decreased strongly EVPT of osteospermum and in lesser extent EVPT of impatiens. Osteospermum irrigated at $-0,5 \mathrm{kPa}$ had 2,5 higher EVPT than impatiens.

For both plants good, positive correlation between EVPT and daily mean temperature, temperature between $7-17 \mathrm{~h}$ and evaporation according to Piche's evaporometer readings were obtained. As expected EVPT was negatively correlated with relative humidity, irrespective the growth phase and soil water potential. The correlation between EVPT and solar radiation, was changed during plant growth due to differences in temperature under shading screen, used during sunny days.

Key words: osteospermum, New Guinea impatiens, evapotranspiration, ebband-flow benches, leaf area index 


\section{INTRODUCTION}

One of the main factors influencing plant growth, flowering and quality during production phase on ebb-and-flow benches is proper irrigation regime. In the case of too frequent irrigation, excess of water and lack of oxygen in the root environment could suppress plant growth ( $\mathrm{N}$ o w a k, 2000). However, insufficient irrigation led to excessive drying of the growing medium between the irrigations, worse wettability and lowered plant growth rates. Many authors concluded that water relations in the growing media, used in subirrigation system, are very important for proper plant growth (B e 1 1, 1988; D e K rei j, S traver, 1988; Treder et al., 2000).

In modern greenhouses, automated irrigation systems are usually used to modify irrigation frequency according to evapotranspiration ( $N$ o r r i e et al., 1994; O t t e n et al., 1999; M u n o z-C a r p e n a et al., 1995). During the irrigation on ebb-and-flow benches, timing about 10-15 minutes, the amount of retained water is depended of kind of growing medium and size of pots. To ensure plant growth, the water losses by evapotranspiration should be lower than the amount of water taken up by the medium during irrigation (B a i 11 e et al., 1994a). Evapotranspiration of plants is affected by many factors, either plant related: growth stage, leaf area, stomatal conductance; kind of growing medium; water availability; climatic factors i.e. temperature, solar radiation, humidity and combination of these factors like leaf temperature and moisture deficit between leaf and glasshouse air (B a i 11 e et al., 1994ab, S t a n g h e 11 i n i, van Meurs, 1989).

The objective of this research was to determine how the evapotranspiration of bedding plants: osteospermum and impatiens respond to climatic condition in the greenhouse and water deficit applied during production phase on ebb-and flow benches.

\section{MATERIALS AND METHODS}

The experiment was carried out with osteospermum (Osteospermum ecklonis (DC) Norl.) 'Denebola' and New Guinea impatiens (Impatiens hawkerii Bull.) 'Timor' grown on ebb-and-flow benches. Osteospermum were grown in spring trial (from 10 March to 25 May) whereas impatiens in summer trial (from 28 July to 6 October). There were four irrigation treatments according to soil water potential (irrigation at $-0.5 ;-3 ;-10$ and $-20 \mathrm{kPa}$ ). Plants from each water treatment were grown separately on different benches. All details about greenhouse conditions, plant growth procedures, plant spacing and fertigation were described previously ( $\mathrm{T} \mathrm{r}$ e d e r, N o w a k, in print).

Evapotranspiration (EVPT) was determined by weighing plants with pots. There were 6 uniform plants randomly sampled from each water treatment for these purposes. Plants were weighed in the morning, about 30 minutes after irrigation (when the excess of water drained out) and the day after, just before irrigation. Plants were irrigated if the soil tension reached the desired level. The determinations of EVPT were made during 12 days when plants reached specified growth phase: lateral shoots spro- 
uting, visible flower buds and flowering for osteospermum and shoot sprouting, beginning of flowering and full flowering for impatiens. Estimation of leaf area index (LAI) was performed at each growth phase by measuring leaf area of ten plants, randomly selected from each treatment, using leaf area meter (Delta-T Devices LTD, Cambridge, UK) and dividing the results by growing area. For the same days, when plants were weighed for EVPT determinations, the climatic conditions in the greenhouse like: the incoming daily, solar radiation (phytophotometer 'Step' Białystok, Poland), average, relative humidity (HOBO RH Logger, Spectrum Technologies, USA) and temperature were recorded. Solar radiation was measured under the screen, on the plant level. The ability to evaporation in the given conditions in the greenhouse (created by coexistence of climatic factors like light, temperature, humidity and air velocity) was measured using Piche's evaporometer. This is vertical, glass tube, about $30 \mathrm{~cm}$ long and inside diameter $10 \mathrm{~mm}$, closed on the top and open in the bottom. After filling with pure, distilled water this tube is closed with paper disc ( $4 \mathrm{~cm}$ of diameter) held by wire ring and hanged vertically in the greenhouse. The Piche's evaporometer readings (quantity of water evaporated during fixed period from the paper disc) could be related to the water evaporation from open, water space ( $\mathrm{R} \mathrm{a} \mathrm{d} \mathrm{o} \mathrm{m} \mathrm{s} \mathrm{k} \mathrm{i,} \mathrm{1979).}$

The values of leaf area index at each growing phase were calculated and submitted to analysis of variance. The means were tested by Duncan's multiple range test. The relations between values of EVPT as a function of climatic conditions inside the greenhouse were calculated using regression analysis. Results were presented as regression coefficients between analyzed parameters.

\section{RESULTS AND DISCUSSION}

Drought stress, appeared when evaporative demand exceeded water uptake, significantly restricted plant growth and leaf areas of osteospermum and impatiens ( $\mathrm{T} \mathrm{r}$ e d e r, N o w a k, 2001) and consequently stressed plants had lower LAI (Tab. 1). The interaction between plant growth phase and soil water potential was found with respect to LAI of both plants. Young plants, at lateral shoots sprouting, did not shown visible symptoms of water stress and their LAI was not significantly different. However, during the next growing phases of osteospermum: at visible flower buds and at flowering, LAI decreased as drought stress increased. The decrease of LAI between irrigation at $-0,5$ and $-20 \mathrm{kPa}$ was $31 \%$ at visible flower buds and $37 \%$ at flowering. In the case of impatiens the most favorable for plant growth was irrigation at $-3 \mathrm{kPa}$, irrespective the growth phase. $\mathrm{H}$ a v e r and $\mathrm{S} \mathrm{c} \mathrm{h} \mathrm{u} \mathrm{ch} \mathrm{(1996)} \mathrm{obtained} \mathrm{also}$ the best growth of impatiens if plants were irrigated between -1 to $-3 \mathrm{kPa}$ of soil tension. As results of moderate water stress potted roses maintained leaf number but reduced their area by $20 \%$. However, when plants were exposed to severe water stress both leaf number and leaf area were reduced by $40 \%$. (W i 11 i a m s et al. 1999).

Daily EVPT of young osteospermum (shoots sprouting phase), was almost twice lower than that for impatiens, irrespective the water treatment (Fig. 1). Possible explanations for this are: lower leaf area and lower temperature in the greenhouse with young osteospermum plants. EVPT of osteospermum increased with plant growth, 
Table 1

Index LAI $\left[\mathrm{m}^{2} \mathrm{~m}^{-2}\right]$ of osteospermum 'Denebola' and New Guinea impatiens 'Timor' as affected by growth stage and soil water potential

\begin{tabular}{|c|c|c|c|}
\hline $\begin{array}{c}\text { Growth } \\
\text { phase }\end{array}$ & $\begin{array}{c}\text { Soil water } \\
\text { potential } \\
(\mathrm{kPa})\end{array}$ & $\begin{array}{c}\text { Osteospermum } \\
\text { 'Denebola' }\end{array}$ & $\begin{array}{c}\text { Impatiens } \\
\text { 'Timor }\end{array}$ \\
\hline $\mathrm{I}^{2}$ & -0.5 & $0.32 \mathrm{a}$ & $0.49 \mathrm{a}$ \\
& -3. & $0.39 \mathrm{a}$ & $0.46 \mathrm{a}$ \\
& -10 & $0.36 \mathrm{a}$ & $0.44 \mathrm{a}$ \\
\hline II & -20 & $0.25 \mathrm{a}$ & $1.25 \mathrm{bc}$ \\
& -3.0 & $1.83 \mathrm{ef}$ & $1.31 \mathrm{c}$ \\
& -10 & $1.62 \mathrm{~d}$ & $1.16 \mathrm{~b}$ \\
\hline III & -20 & $1.37 \mathrm{bc}$ & $1.62 \mathrm{~d}$ \\
& -0.5 & $1.93 \mathrm{~b}$ & $1.88 \mathrm{e}$ \\
& -3.0 & $1.69 \mathrm{de}$ & $1.29 \mathrm{c}$ \\
\hline \multicolumn{2}{|l|}{ Significance level } & $1.45 \mathrm{c}$ & $* *$ \\
Growth phase & -20 & $* *$ & $* *$ \\
\hline Soil water potential & $* *$ & $\mathrm{bc}$ & \\
Interaction & & $* *$ & \\
\hline
\end{tabular}

\section{Explanations:}

Values followed by the same letter in columns are not different at $5 \%$ level of significance, according to Duncan's range test, ** means: significant at 0,01 .

z - growth phases I, II, III means: shoots sprouting, visible flower buds, flowering for osteospermum and shoot sprouting, beginning of flowering and full flowering for impatiens 
Table 2.

The correlation coefficients of evapotranspiration vs. climatic conditions in the greenhouse for Osteospermum 'Denebola' in different growth phases.

\begin{tabular}{|c|c|c|c|c|c|}
\hline $\begin{array}{l}\text { Soil water } \\
\text { potential } \\
(\mathrm{kPa})\end{array}$ & $\begin{array}{l}\text { Mean daily } \\
\text { temperature }\end{array}$ & $\begin{array}{c}\text { Mean } \\
\text { temperature } \\
\text { in range } \\
7-17 \mathrm{~h}\end{array}$ & $\begin{array}{l}\text { Daily solar } \\
\text { radiation } \\
\text { below the } \\
\text { screen }\end{array}$ & $\begin{array}{l}\text { Relative } \\
\text { humidity }\end{array}$ & $\begin{array}{l}\text { Evaporation } \\
\text { according to } \\
\text { Piche's } \\
\text { evaporometer }\end{array}$ \\
\hline \multicolumn{6}{|c|}{ Shoots sprouting } \\
\hline-0.5 & $0.66^{*}$ & $0.57 *$ & 0.23 & $-0.67 *$ & $0.93 *$ \\
\hline-3.0 & $0.64 *$ & $0.53 *$ & $0.60 *$ & $-0.43 *$ & $0.66 *$ \\
\hline-10 & $0.70^{*}$ & $0.70^{*}$ & $0.41 *$ & $-0.66 *$ & $0.66 *$ \\
\hline-20 & $0.73 *$ & $0.73^{*}$ & $0.36^{*}$ & $-0.68 *$ & $0.68 *$ \\
\hline \multicolumn{6}{|c|}{ Visible flower buds } \\
\hline-0.5 & $0.45^{*}$ & $0.55^{*}$ & -0.23 & -0.12 & $0.40^{*}$ \\
\hline-3.0 & $0.30^{*}$ & $0.46^{*}$ & $-0.46^{*}$ & $-0.45^{*}$ & $0.68 *$ \\
\hline-10 & $0.43 *$ & $0.44 *$ & -0.08 & -0.15 & $0.68 *$ \\
\hline-20 & $0.32 *$ & $0.38 *$ & -0.22 & $-0.39 *$ & $0.60 *$ \\
\hline \multicolumn{6}{|c|}{ Flowering } \\
\hline-0.5 & $0.61 *$ & 0.36 & $-0.55^{*}$ & $-0.52 *$ & 0.35 \\
\hline-3.0 & $0.95 *$ & $0.89 *$ & $-0.96^{*}$ & $-0.44 *$ & $0.67 *$ \\
\hline-10 & $0.80 *$ & $0.87 *$ & $-0.83 *$ & -0.27 & $0.62 *$ \\
\hline-20 & $0.52 *$ & $0.69 *$ & $-0.59 *$ & -0.16 & $0.66^{*}$ \\
\hline \multicolumn{6}{|c|}{ Mean results for three growth phases } \\
\hline-0.5 & $0.84 *$ & $0.85 *$ & $0.83^{*}$ & $-0.51 *$ & $0.73^{*}$ \\
\hline-3.0 & $0.70^{*}$ & $0.73 *$ & $0.79 *$ & $-0.47 *$ & $0.66^{*}$ \\
\hline-10 & $0.75^{*}$ & $0.78 *$ & $0.87 *$ & $-0.42 *$ & $0.62 *$ \\
\hline-20 & $0.65 *$ & $0.70 *$ & $0.70 *$ & $-0.50 *$ & $0.63 *$ \\
\hline
\end{tabular}

Explanations:

* Correlation is significant at $\mathrm{p}<0,05$. 
Table 3

The correlation coefficients linking evapotranspiration of New Guinea impatiens 'Timor' to climatic conditions in the greenhouse

\begin{tabular}{|c|c|c|c|c|c|}
\hline $\begin{array}{c}\text { Soil water } \\
\text { potential } \\
(\mathrm{kPa})\end{array}$ & $\begin{array}{c}\text { Mean daily } \\
\text { temperature }\end{array}$ & $\begin{array}{c}\text { Mean } \\
\text { temperature } \\
\text { in range } \\
7-17 \mathrm{~h}\end{array}$ & $\begin{array}{c}\text { Daily solar } \\
\text { radiation } \\
\text { below the } \\
\text { screen }\end{array}$ & $\begin{array}{c}\text { Relative } \\
\text { humidity }\end{array}$ & $\begin{array}{c}\text { Evaporation } \\
\text { according to } \\
\text { Piche's } \\
\text { evaporometer }\end{array}$ \\
\hline \multicolumn{6}{|c|}{ Shoots sprouting } \\
\hline-0.5 & $0,41^{*}$ & $0,35^{*}$ & $0,83^{*}$ & $-0,83^{*}$ & $0,78^{*}$ \\
-3.0 & $0,53^{*}$ & $0,48^{*}$ & $0,80^{*}$ & $-0,90^{*}$ & $0,85^{*}$ \\
\hline-10 & $0,64^{*}$ & $0,61^{*}$ & $0,68^{*}$ & $-0,90^{*}$ & $0,81^{*}$ \\
\hline-0.5 & $0,87^{*}$ & $0,90^{*}$ & $-0,12$ & $-0,94^{*}$ & $0,88^{*}$ \\
\hline-3.0 & $0,86^{*}$ & $0,89^{*}$ & $-0,07$ & $-0,90^{*}$ & $0,86^{*}$ \\
\hline-10 & $0,84^{*}$ & $0,87^{*}$ & $-0,04^{*}$ & $-0,89^{*}$ & $0,84^{*}$ \\
\hline \multicolumn{6}{|c|}{ Beginning flowering } \\
\hline-0.5 & 0,26 & $0,65^{*}$ & $0,36^{*}$ & $-0,82^{*}$ & $0,90^{*}$ \\
\hline-3.0 & $0,28^{*}$ & $0,69^{*}$ & $0,28^{*}$ & $-0,82^{*}$ & $0,86^{*}$ \\
-10 & $0,34^{*}$ & $0,78^{*}$ & $0,41^{*}$ & $-0,81^{*}$ & $0,91^{*}$ \\
\hline \multicolumn{6}{|c|}{ Mean results for three growth phases } \\
\hline-0.5 & $0,49^{*}$ & $0,54^{*}$ & $0,49^{*}$ & $-0,84^{*}$ & $0,83^{*}$ \\
\hline-3.0 & $0,58^{*}$ & $0,63^{*}$ & $0,54^{*}$ & $-0,85^{*}$ & $0,83^{*}$ \\
\hline-10 & $0,68^{*}$ & $0,75^{*}$ & $0,58^{*}$ & $-0,79^{*}$ & $0,77^{*}$ \\
\hline
\end{tabular}

Explanations:

* Correlation is significant at $\mathrm{p}<0,05$. 
up to flowering, especially when plants were irrigated at $-0.5 \mathrm{kPa}$. At flowering EVPT decreased as a result of drought stress by $48 \%$. In the case of impatiens EVPT remained at similar level in all growth phases if plant were irrigated at $-0.5 \mathrm{kPa}$ or decreased if plants were exposed to lower soil water potential. O t t e n et al. (1999) reported that daily EVPT of $F$. benjamina grown on ebb-and-flow benches ranged from 0.4 to 4.1 $\mathrm{mm}$, depending of the plant growth stage and weather conditions.

The correlation coefficients linking EVPT of osteospermum and impatiens to climatic conditions in the greenhouse, analyzed at three growth phases, are presented in tables 2 and 3. High and positive correlation between EVPT and mean diurnal temperature, as well as between EVPT and mean day temperature, was obtained for osteospermum (Tab. 2). In the case of impatiens, mean day temperature measured between 7 - $17 \mathrm{~h}$ influenced stronger EVPT than mean diurnal temperature (Tab. 3). Evaporation from soil surface in the pots appears all the time, whereas transpiration when stomata are open only during light hours of the day. Impatiens showed higher stomatal conductance than osteospermum, irrespective the soil water potential ( $\mathrm{T} \mathrm{r}$ e d e r and N ow a k, 2001).

Solar radiation measured at the plant level (below the screen) influenced positively EVPT of osteospermum at the stage of lateral shoot sprouting only (Tab. 2). However, EVPT of plants irrigated at $-0.5 \mathrm{kPa}$ were not correlated with solar radiation. At visible flower buds and at flowering stages EVPT was negatively correlated with solar radiation. Similar results were obtained for impatiens (Tab. 3). Daily solar radiation was highly and positively correlated with EVPT at lateral shoot sprouting only. When impatiens began to flower EVPT was not correlated with this climatic parameter. Lack of correlation between solar radiation and EVPT, as well as negative correlation, have been due to plant screening during sunny and hot days, appeared when both plants started to flower. Similar results have been shown for Hedera and Dieffenbachia (T re de r et al., 1997). Using shadow screen decreased sharply light level under screen, whereas temperature decreased in much lower extent and this phenomena was responsible for lack of positive correlation between EVPT and solar radiation measured under unstable greenhouse conditions. For this reason the correlation coefficients between solar radiation and EVPT cannot be used for further considerations. As solar radiation level usually remains beyond the reach of greenhouse climate control management or the means for manipulation of radiation are limited, EVPT in shaded or lighted greenhouse is primarily determined by two climatic fac'tors: temperature and humidity. It has been shown in many reports that if plants are not screened during growth, solar radiation, together with other climatic factors are highly correlated with actual EVPT and could be used for predicting potential EVPT of gerbera (M a l o u p a et al., 1993), roses (B a i l l e et al., 1994b), tomato (O k u y a and O k u y a, 1988) and cucumber (Y a ng et al., 1990).

As expected, the EVPT of both plants was negatively correlated with humidity irrespective the growth phase and soil water potential. High correlation between moisture deficit (leaf/glasshouse air) and daily transpiration of rose has been shown by $\mathrm{d}$ e $\mathrm{G} \mathrm{r}$ a a $\mathrm{f}$ (1995). The calculation of potential EVPT, based on climatic sensors, allows predicting water requirements and thus automatic control of irrigation. The results indicating high correlation of EVPT and Piche's evaporometer readings are 


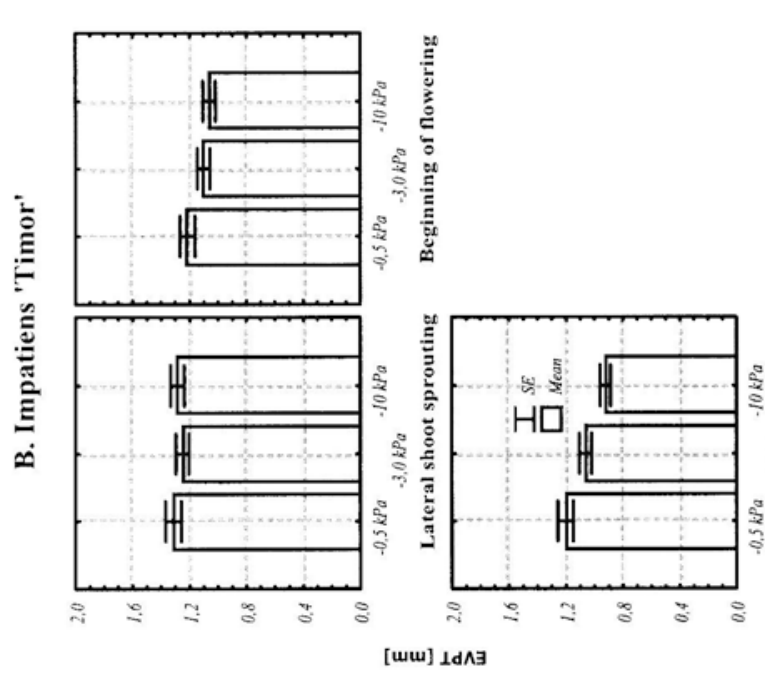

送

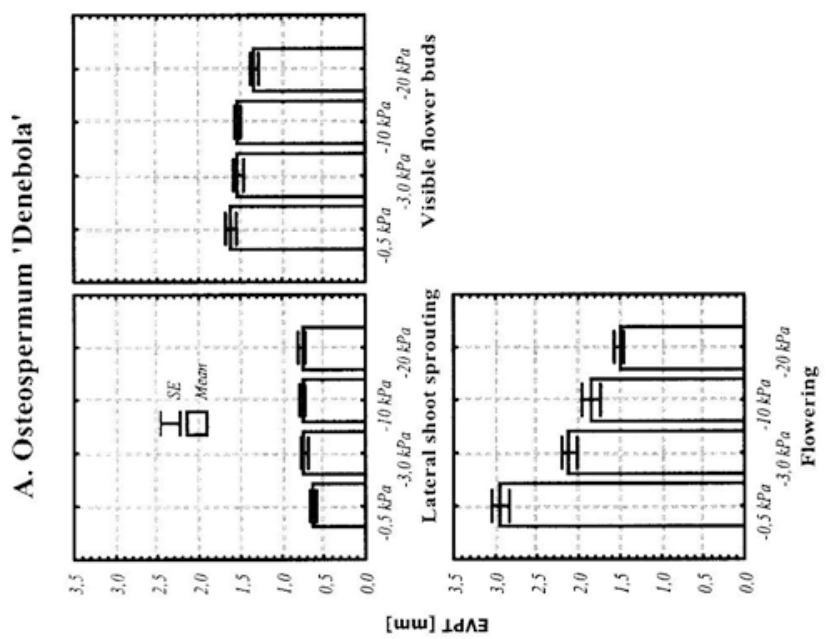

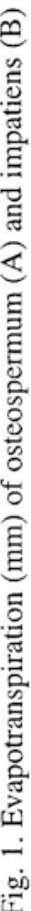


difficult to discuss due to lack of information in the literature concerning this problem. It seems to be possible that simple Piche's evaporometer measurement can also be used for irrigation frequency control, as correlations between these readings and EVPT were very high and significant for both plants.

The results of present study confirmed previous reports that EVPT is correlated with most climatic factors inside the greenhouse. According to S $\mathrm{t}$ a $\mathrm{ng}$ h $\mathrm{ll}$ in $\mathrm{i}$ and $\mathrm{v}$ a n M e u r s (1989) calculation of EVPT based on solar radiation is limited if shadow screens or lighting system is used.

\section{Acknowledgement}

The financial support of Polish State Committee for Scientific Research, Project No. 0691/PO6/98/15 (1998-2001) is gratefully acknowledged.

\section{REFERENCES}

B a i 1 l e M., B a i 11 e A., L a u r y J. C. 1994a. A simplified model for predicting evapotranspiration rate of nine ornamental species vs. climate factors and leaf area. Scientia Hort. 59: 217-232.

B a ille M., B a ille A., D e 1 m o n D. 1994b. Microclimate and transpiration of greenhouse rose crops. Agriculture and Forest Meteorology. 71 (1-2): 83-97.

B e 11 E. 1988. Substrates for greenhouse plants cultivated with several irrigation systems. Acta Hort. 221, 315-326.

$\mathrm{Gr}$ a a f, de R. 1995. Influence of moisture deficit, leaf-air cultural practices on transpiration of glasshouse roses. Acta Hort. 401: 545-552.

$\mathrm{H}$ a ve r D. L., S c h u c h U. K. 1996. Production and postproduction performance of two New Guinea impatiens cultivars grown with controlled-release fertilizers and no leaching. J. Amer. Soc. Hort. Sci. 121: 820-825.

K re i j, de C. and S traver N. 1988. Flooded bench irrigation: Effect of irrigation frequency and type of potting and type of potting soil on growth of Codiaeum and nutrient accumulation in the soil. Acta Hort. 221: 245-252.

Maloupa E., Papadopoulos A., B ladenopoulou S., Lopez-Galvez J. 1993. Evapotranspiration and preliminary crop coefficient of gerbera soilless culture grown in plastic greenhouse. Acta Hort. 335: 519-526.

Munoz-Carpena R., Socorro-Monzon A.R., Mansito P., Trujillo J., M or i s o t A., R i c c i P. 1996. Irrigation management based on water consumption, for greenhouse roses growing on teracce soils in the Canary Islands. Acta Hort. 424: 111-114.

N ow a k J. 2000. The effect of water potential of growing medium on growth, flowering and alcohol dehydrogenase activity of Osteospermum cultivated on ebb-and-flow benches. Horticulture, 19 (3): 514-520.

N or ri e J., Grah a m M. E. D., G o s s e l i n A. 1994. Potential evapotranspiration as a means of predicting irrigation timing in greenhouse tomato grown in peat bags. J. Amer. Soc. Hort. Sci., 119: 163-168.

Otte n W., R a a t s P. A. C., B a a s R., Ch a 11 a H., K a b a t P. 1999. Spatial and temporal dynamics of water in the root environment of potted plants on flooded bench fertigation system. Neth. J. of Agric. Sci. 47 (1): 51-65.

O k u y a A., O k u y a T. 1988. The transpiration of greenhouse tomato plants in rockwool culture and its relationship to climatic factors. Acta Hort. 230: 307-311.

R a d o m s k i Cz. 1979. Agrometeorologia. PWN, Warszawa, pp 543. 
Treder J., M a ty siak B., Now a k J. 2000. Evaluation of different peat/wool substrates for cyclamen and poinsettia grown on ebb-and-flow benches. Zesz. Naukowe ISK, Skierniewice Vol. 7: 99-104 (in polish).

Treder J., M at y si a k B., N ow a k J., Treder W. 1997. Evapotranspiration and potted plants water requirements as affected by environmental factors. Acta Hort. 449. Vol. 1: 235-239.

T rede r J., N ow a k J. 2001. The effect of irrigation frequencey on growth, flowering and stomatal conductance of osteospermum 'Denebola' and New Guinea impatiens 'Timor'grown an ebb-and-flow benches. Acta Agrobotanica, Vol. 54, z. 2:59-68

S t a n g hellin I. C., V a n Me ur s W. T.M. 1989. Crop transpiration: a greenhouse climate control parameter. Acta Hort. 245-388.

W i 11 i a m s M., R o s e n q vis t E., B u $\mathrm{ch}$ h a ve M. 1999. Response of potted miniature roses (Rosa $x$ hybrida) to reduced water availability during production. J. Hort. Sci and Biotechn. 74 (3) 301-308.

Y a n g X., S hort T. H., F ox R. D., B a u e r l e W. L. 1990. Transpiration, leaf temperature and stomatal resistance of a greenhouse cucumber crop. Agricultural and Forest Meteorology. 51: 197-209. 


\title{
Zależność ewapotranspiracji osteospermum 'Denebola' i niecierpka nowogwinejskiego 'Timor', uprawianych na stołach zalewowych przy różnym potencjale wodnym podłoży od czynników klimatycznych w szklarni
}

\author{
Streszczenie
}

Badano metodą wagową ewapotranspirację (EVPT) dobową osteospermum 'Denebola' i niecierpka nowogwinejskiego „Timor” uprawianych na stołach zalewowych. Częstotliwość nawadniania roślin oparto na pomiarach siły ssącej podłoża. Osteospermum nawadniano przy $-0.5,-3.0,-10,0 \mathrm{i}-20 \mathrm{kPa}$, a niecierpek podobnie, $\mathrm{z}$ pominięciem ostatniego poziomu $(-20 \mathrm{kPa})$. Podczas wzrostu roślin kontrolowano parametry klimatyczne w szklarni (temperaturę, natężenie światła, wilgotność oraz parowanie za pomocą ewaporometru Piche'a). W trzech fazach rozwojowych: krzewienia, fazy widocznych pąków i kwitnienia u osteospermum oraz fazy krzewienia, początku kwitnienia i pełni kwitnienia u niecierpka zmierzono wskaźnik pokrycia liśćmi (LAI) oraz EVPT.

Zmniejszenie częstotliwości nawadniania roślin ograniczało tempo wzrostu oraz powierzchnię liści obydwu gatunków. Indeks LAI osteospermum zmniejszał się w miarę wzrostu potencjału wodnego podłoża. Najwyższym poziomem LAI cechował się niecierpek nawadniany przy potencjale wodnym $-3 \mathrm{kPa}$. EVPT osteospermum nawadnianego przy potencjale $-0,5 \mathrm{kPa}$ zwiększało się w miarę wzrostu roślin, zaś EVPT niecierpka pozostała na zbliżonym poziomie. Podlewanie przy wysokim potencjale wodnym podłoża silnie zmniejszyło EVPT w czasie kwitnienia osteospermum, zaś w dużo mniejszym stopniu EVPT niecierpka. Osteospermum w czasie kwitnienia cechowało się 2,5 raza wyższym poziomem EVPT, niż niecierpek w analogicznej fazie wzrostu.

U obydwu badanych gatunków stwierdzono dodatnią korelację pomiędzy EVPT a średnią dobową temperaturą, średnią temperaturą w godz. 7-17 oraz parowaniem mierzonym ewaporometrem Piche’a. Zgodnie z oczekiwaniami EVPT była ujemnie skorelowana $\mathrm{z}$ wilgotnością względną powietrza w szklarni. Korelacja pomiędzy EVPT a światłem mierzonym na poziomie roślin zmieniała się w zależności od fazy wzrostu oraz potencjału wodnego podłoża. Korelacja ujemna lub brak istotnej zależności pomiędzy badanymi cechami w niektórych fazach wzrostu roślin były wynikiem utrzymywania się wysokiej temperatury pomimo silnego cieniowania roślin przy słonecznej pogodzie. 